\title{
Flecainide in Cadaveric Blood and Tissues
}

\author{
Vezzoli Sara, Conti Adelaide and Bernini Marzia \\ Department of Legal Medicine, University of Brescia, Brescia 25123, Italy
}

\begin{abstract}
In this report, we described a death caused by a deliberate overdose of Flecainide acetate (Almarytm ${ }^{\circledR}$ ), an antiarrhythmic agent. The patient had taken a box of 20 Almarytm ${ }^{\circledR} 100 \mathrm{mg}$ tablets. The Flecainide concentration found in the post-mortem cardiac blood was $10.16 \mathrm{mg} / \mathrm{L}$. This concentration could not have been determined by post-mortem diffusion of the drug from gastric residue because the patient was previously given activated carbon during the emergency procedure. In fact, in the peripheral blood, the Flecainide concentration was $8.64 \mathrm{mg} / \mathrm{L}$, therefore, this concentration is overlapping with the concentration in the cardiac blood; the gastric content was negative at the screening of Flecainide, while the liver tissue concentration of Flecainide was $59.6 \mathrm{mg} / \mathrm{L}$ and the bile concentration was $128 \mathrm{mg} / \mathrm{L}$. The brain tissue concentration of Flecainide was $4.19 \mathrm{mg} / \mathrm{L}$. In this case, the cause of death, excluding that toxicity was depending on post-mortem gastric diffusion of the drug, because of the absorbing activity of the administered carbon at the recovery.
\end{abstract}

Key words: Flecainide, antiarrhythmic, cadaveric blood, gastric content.

\section{Introduction}

Flecainide acetate $\quad(2,5 \quad$ bis $\quad(2,2,2-$ trifluoroeth-oxy)-N-(2-piperidylmethil) benzamide acetate MEDA PHARMA) is a sodium channel blocking agent, very effective as antiarrhythmic drug, used in the treatment of ventricular arrhythmias [1]. Flecainide is characterized by good patient tolerance and by a broad spectrum of activity, in fact, it is indicated for the treatment of various arrhythmias including the ventricular arrhythmias [2], as reported also in a recent revue on the management of AF (atrial fibrillation) by Flecainide [3].

Flecainide also has local anaesthetic properties that depress cardiac contractility. After oral administration, Flecainide is rapidly absorbed and peak plasma concentrations occur after $0.5 \sim 6 \mathrm{~h}$, with a long plasma half-life of $11 \mathrm{~h}$. Its apparent volume of distribution is high, about $8.7 \mathrm{~L} / \mathrm{kg}$, and its plasma protein binding is around 40\%. Flecainide undergoes biotransformation via O-dealkylation with the forming of two main metabolites: meta-O-dealkylated Flecainide and meta-O-dealkylated lactam of Flecainide. Both can be

Corresponding author: Bernini Marzia, professor, research field: forensic medicine. conjugated further [4].

Its plasma pharmacokinetics have been extensively described [5]. The therapeutic levels in serum range between $0.2 \mathrm{mg} / \mathrm{L}$ and $1 \mathrm{mg} / \mathrm{L}$. Flecainide is considered toxic at the concentration of $1 \mathrm{mg} / \mathrm{L}$ [6]. In toxic doses, hypotension arises rapidly, and the resulting reduction in hepatic and renal blood flow would decrease Flecainide elimination from blood [7]. Post-mortem blood concentration of $13 \mathrm{mg} / \mathrm{L}$ and 16.3 $\mathrm{mg} / \mathrm{L}$ were reported in several studies following ingestion of Flecainide [8,9]. Overdosing can cause or worsen supraventricular or ventricular arrhythmias and cause heart failure. Overdosage by mouth should be treated by removing the drug from the stomach through lavage, followed by activated charcoal; haemodialysis or haemoperfusion are unlike to enhance elimination [7-11]. In this case, activated charcoal was administered to the patient.

The present work evaluates the distribution of Flecainide in human tissues and studies the possible exclusion of post-mortem gastric diffusion of this drug caused by the absorbing activity of carbon given during the emergency rescue attempt.

In order to demonstrate this, samples of cardiac blood, peripheral blood, liver, bile, gastric residue and 
brain tissue were analyzed after homogenization.

\section{Material and Methods}

\subsection{Case History}

The patient was a 58-year-old woman, suffering of atrial fibrillation, clinically under treatment with Flecainide $\left(\right.$ Almarytm $\left.^{\circledR}\right)$; recently she changed her dosage, from $1 / 4$ tablet of Flecainide two times a day to $1 / 2$ tablet two time a day.

She committed suicide in December 22, 2009. Regarding circumstances of her death, the husband declared that he had discovered an empty box containing around 20 tablets of Almarytm ${ }^{\circledR}$.

Other relevant information comes from reports made available at the hospital: at midnight the patient arrived unconscious and without pulse. Immediately she sent to the ICU (intensive care unit) with a diagnosis of abuse of antidysrhythmic, she had a serious insufficiency cardio circulatory and the medics did a gastrolysis with active carbon $50 \mathrm{~mL}$ and dopamine's infusion.

During the night, the atrial pressure was 50/30. At 7:30 a.m., the clinic conditions were terminal; as a matter of fact, there were absence of spontaneous respiration, absence of trunk reflex, pulselessness and hypothermal. She was declared dead around 9:00 in the morning.

Unfortunately, the blood specimens carried out in order to the clinic control are eliminated to the laboratory of the therapy unit. During the autopsy, carried out $24 \mathrm{~h}$ after her death, there was no evidence of significant natural disease and no other significant pathological findings.

The heart was morphologically normal; the cardiac arteries presented a light atherosclerotic damage near the origin of the right anterior descending.

The heart was morphologically normal and the coronary arteries were free of atheroma.

Cardiac and femoral blood, gastric residue, liver, bile and brain cortex were sampled for toxicological analysis. Based on the toxicology investigation, the cause of death was defined.

\subsection{Toxicological Analyses}

Flecainide acetate was obtained from MEDA PHARMA s.p.a while Nalorfine $\mathrm{HBr}$ standard was obtained from S.A.L.A.R.S. (Via San Francesco 5-22100 Como Italy)

A stoke standards solution containing Flecainide acetate was prepared by appropriate dilution in water intravenous use from the mother solution; standards were stored at the temperature of $4{ }^{\circ} \mathrm{C}$.

Other chemicals and solvents were analytical reagent graded. Sylon MSTFA (N-Methyl-N-(trimethyl-sylyl) trifluoroacetamide) was purchased from Sigma-Aldrich (St. Louis, MI, USA).

Blood and tissue samples were collected and frozen at the temperature of $-20{ }^{\circ} \mathrm{C}$ until analyzed.

Peripheral and cardiac blood, liver, bile, brain and gastric residue samples were added to $4 \mathrm{~mL}$ of phosphate buffer $\mathrm{pH}=6$ and sonicated for $60 \mathrm{~min}$.

Then the samples were centrifugated at $3,000 \mathrm{rpm}$ for $30 \mathrm{~min}$. The $\mathrm{pH}$ values of supernatant were measured and fixed to $\mathrm{pH} 6$ through $\mathrm{NaOH} 1 \mathrm{~N}$.

The samples were extracted using Bond Elute Certify ${ }^{\circledR}$ (Varian Palo Alto, CA) cartridges.

The cartridges were activated by pouring twice $2 \mathrm{~mL}$ of methanol and $2 \mathrm{~mL}$ of phosphate buffer $\mathrm{pH}=6$.

All samples were spiked with Nalorfine methanol solution, the internal standard, at $0.2 \mathrm{mg} / \mathrm{L}$ and then added to the cartridge. The column was washed with $3 \mathrm{~mL}$ of Millipore ${ }^{\circledR}$ water, $3 \mathrm{~mL}$ of $\mathrm{HCl} 0.1 \mathrm{~N}$ and $5 \mathrm{~mL}$ of methanol. The samples were eluted by solution of Diclorometane: 2-Propanol: Ammonium hydroxide (20:5:0.5), $2 \mathrm{~mL}$.

Then the elute was evaporated under a gentle stream of nitrogen gas. The residue was resuspended in $0.05 \mathrm{~mL}$ of MSTFA (N-Methyl-N-(trimethyl-sylyl) trifluoroacetamide) and derivatizated at the temperature of $70{ }^{\circ} \mathrm{C}$ for $30 \mathrm{~min}$.

For the screening analysis, an Agilent 6890 gas chromatograph was used in combination with a HP 
MSD series 5973 mass spectrometer. The GC conditions were as followed: splitless injection mode (purge time $1 \mathrm{~min}$ ); HP 5MS 5\% phenyl-metyl-silicone capillary column $15 \mathrm{~m}, 0.25 \mathrm{~mm}, 0.25 \mu \mathrm{m}$ film thickness; Injector port temperature: $250{ }^{\circ} \mathrm{C}$; Oven temperature programmed: $100{ }^{\circ} \mathrm{C}$; (initial time 2.25 min) then $180^{\circ} \mathrm{C}$ (rate: $40{ }^{\circ} \mathrm{C} / \mathrm{min}$ ) and then to $290^{\circ} \mathrm{C}$ (rate: $10{ }^{\circ} \mathrm{C} / \mathrm{min}$ ); final temperature $310{ }^{\circ} \mathrm{C}$ and final run time: $23.08 \mathrm{~min}$; Carrier gas: helium, constant flow-rate $1 \mathrm{~mL} / \mathrm{min}$.

For the screening investigation, the MS conditions were as followed: scan mode 50-550 a.m.u threshold: $150 \mathrm{scan} / \mathrm{s}$, ionization energy $70 \mathrm{eV}$.

Data were automatically processed with the NIST peak search program and with the NIST identification of peak Mass Spectra Library program (Revision 2008) from Agilent Technologies.

For the quantification analysis an Agilent 7890A Gas-Chromatograph was used in combination with HP MSD series 5975 mass spectrometer. The GC conditions were the same used during screening.

The calibration curves were created: one using flecainide-spiked blood at these concentrations: 0, 1, 2, 2.5, $10,20 \mathrm{mg} / \mathrm{L}$; the second curve using flecainide-spiked brain tissue at the concentrations of: $0,2,2.5,10,25 \mathrm{mg} / \mathrm{L}$. The third curve using flecainide-spiked liver tissue at these concentrations: 0 , $10,25,50,100 \mathrm{mg} / \mathrm{L}$. And finally, the fourth curve has been prepared using flecainide-spiked bile at the concentrations of: $0,10,25,50,100 \mathrm{mg} / \mathrm{L}$.

The quantifications of Flecainide were performed by SIM MODE: the principal ions of the Flecainide-TMS at $156.00 \mathrm{~m} / \mathrm{z}, 301.10 \mathrm{~m} / \mathrm{z}$ and $543.00 \mathrm{~m} / \mathrm{z}$ were selected. The ions of Nalorfine (ISTD) at $313.10 \mathrm{~m} / \mathrm{z}, 324.10 \mathrm{~m} / \mathrm{z}, 414.40 \mathrm{~m} / \mathrm{z}$ and $440.20 \mathrm{~m} / \mathrm{z}$ were selected.

The concentrations of Flecainide in the samples were determined from standard curves. A typical chromatogram is shown in Fig. 1.

\section{Results and Discussion}

The standard curves were linear for Flecainide concentration. Retention times of Flecainide and Nalorfine were, respectively, $7.10 \mathrm{~min}$ and $11.09 \mathrm{~min}$. The calibration curves were linear and presented a least-squares regression model $(y=a x+b)$.

The correlation coefficient of the calibration curves using Flecainide-spiked blood was 0.974 for the $2 \sim 20 \mathrm{mg} / \mathrm{L}$ range and the correlation coefficient of the calibration curves using Flecainide-spiked brain was 0.960 for the $2.5 \sim 25 \mathrm{mg} / \mathrm{L}$ range. The correlation coefficient of the calibration curves using flecainide-spiked liver was 0.957 for the $25 \sim 200 \mathrm{mg} / \mathrm{L}$ range.

The correlation coefficient of the calibration curves using flecainide-spiked in the bile was 0.982 for the range $25 \sim 200 \mathrm{mg} / \mathrm{L}$.

Flecainide concentration in post-mortem cardiac blood was $10.16 \mathrm{mg} / \mathrm{L}$ and in peripheral blood was $8.64 \mathrm{mg} / \mathrm{L}$ : these two concentrations are overlapping. The brain tissue concentration determined by the GC/MS confirmation technique was $4.19 \mathrm{mg} / \mathrm{L}$. In the liver Flecainide concentration was $59.6 \mathrm{mg} / \mathrm{L}$, while in the bile the concentration was $128 \mathrm{mg} / \mathrm{L}$. The results are presented in Table 1.

Post-mortem changes to drug concentration in blood represent an important factor that should be considered when evaluating its value in forensic toxicology. In this case, Flecainide levels in cardiac and peripheral blood are overlapping; Flecainide levels in blood and tissue agree with analogues evaluations in references.

As for Flecainide, its concentrations are reported to be 3.6-fold higher in post-mortem blood than in ante-mortem blood [10].

Two mechanisms of post-mortem have been reported to determine the increase in concentration of a drug: the passive diffusion from gastric residue [12], and post-mortem redistribution from organs containing 

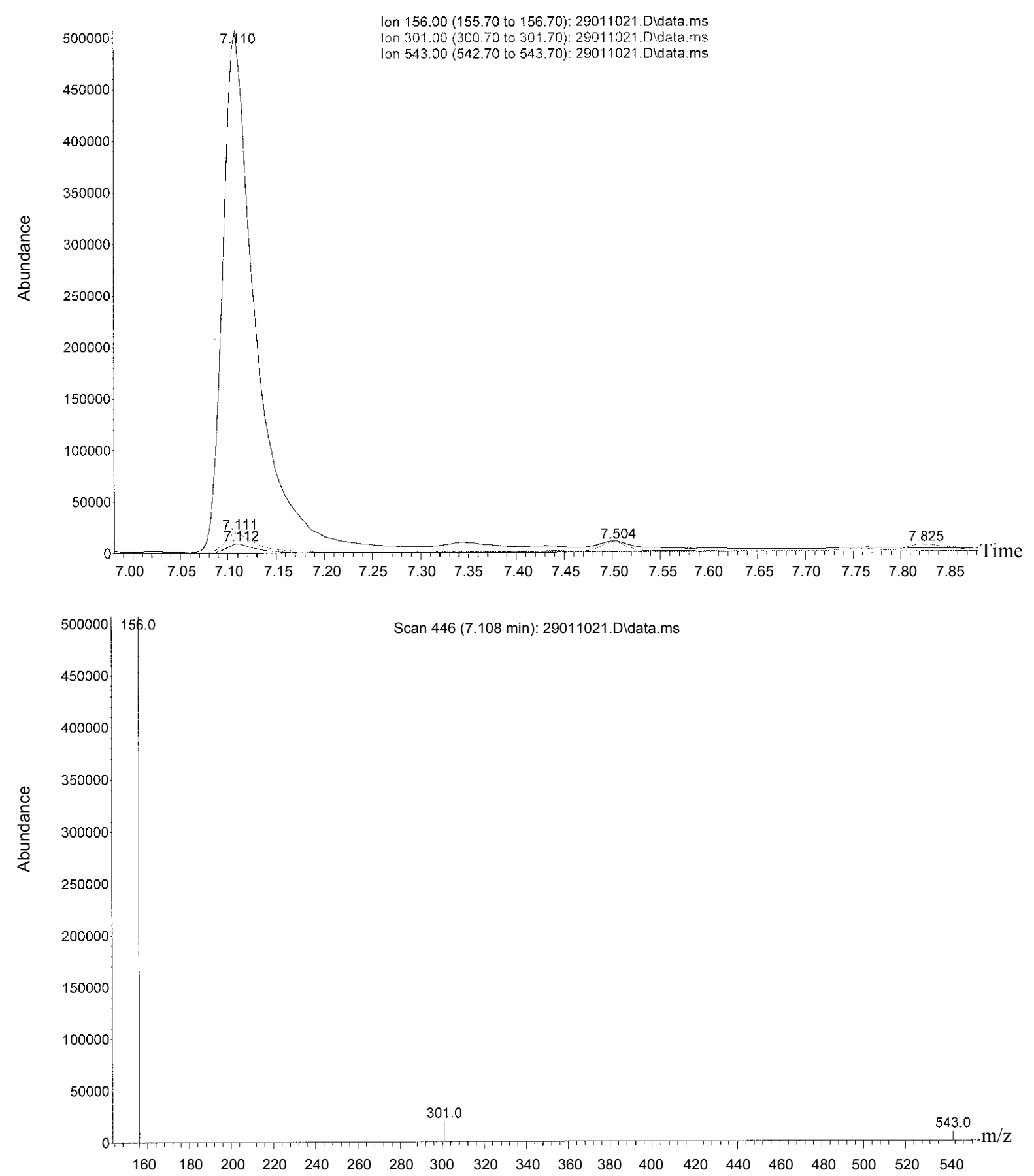

Fig. 1 Characteristic GC/MS spectra of Flecainide-TMS.

Table 1 Flecainide concentrations in fatal cases.

\begin{tabular}{lllllll}
\hline Specimens & $\begin{array}{l}\text { Cardiac blood } \\
(\mathrm{mg} / \mathrm{L})\end{array}$ & $\begin{array}{l}\text { Peripheral blood } \\
(\mathrm{mg} / \mathrm{L})\end{array}$ & Liver $(\mathrm{mg} / \mathrm{L})$ & Bile $(\mathrm{mg} / \mathrm{L})$ & Brain tissue $(\mathrm{mg} / \mathrm{L})$ & Gastric contents $(\mathrm{mg})$ \\
\hline $\begin{array}{l}\text { Present case } \\
\begin{array}{l}\text { References } \\
\text { (range) }\end{array}\end{array}$ & 10.16 & 8.64 & 59.6 & 128 & 4.19 & Negative at screening \\
\hline
\end{tabular}

elevated concentrations of the xenobiotic agent [13].

Many factors can cause an unexpected drug concentration in post-mortem blood: first of all the post-mortem redistribution, represented by the 
movement of drug in the body after death, which may result in higher drug concentration in the subject's blood at autopsy than immediately after death. The event that is most likely to influence this phenomenon is the release of the substance from the organ or tissue to the sorrounding blood, due to variations in $\mathrm{pH}$ levels and to passive diffusion. The latter mechanism is most likely to take place from the stomach content to cardiac and pulmonary blood through the stomach wall [14].

In this case, the possibility of a post-mortem gastric diffusion of the drug appears improbable because of the negative result in the gastric residue by GC/MS technique; in our opinion this fact is due to the absorption activity of activated carbon. The blood concentration is really a consequence of absorbing metabolic activity before reanimation measures.

Nevertheless, redistribution of Flecainide from tissues towards blood vessels is of little importance, without gastric redistribution [9]. The circumstances surrounding the death pointed to a self-poisoning with Flecainide. In fact the toxicological analysis detected that the cardiac blood concentration of Flecainide was far over the range of toxicity; the therapeutic dose of $200 \mathrm{mg}$ corresponds to a plasma concentration of 214 281 $\mu \mathrm{g} / \mathrm{L}$ (average 251) in healthy subjects [5], and the concentration of $3 \mathrm{mg} / \mathrm{L}$ of Flecainide is considered toxic [15].

So, in our opinion, also taking into account that the toxic amount ingested has caused a slowed down metabolism, on the bases of the reported drug levels the cause of death was due to Flecainide overdose.

Furthermore, drug concentration in post-mortem blood has to be carefully evaluated in reference to liver and encephalic levels, along with information from the autopsy and the circumstances of death.

\section{Conclusions}

Flecainide acetate is an antiarrhytmic compound. Overdosing can cause or worsen supraventricular or ventricular arrhythmias and heart failure. However, the interpretation of drugs in post-mortem blood and tissue remains difficult because many drugs are unstable, depending on post-mortem redistribution, and also on the circumstances under which death occurred.

In this suicidal case, the toxicological analysis demonstrated that drug concentration in peripheral blood (far over the range of toxicity), along with tissues concentrations, was the only cause of death, excluding that toxicity was depending on post-mortem gastric diffusion of the drug, because of the absorbing activity of the administered carbon at the recovery.

As in any forensic case of intoxication by drug, the possibility that post-mortem factors (and particularly the redistribution from stomach content to the sorrounding fluids) may determine extremely high concentrations of the examined substances has to be taken into account when evaluating the actual cause of death.

\section{References}

[1] Latini, R., Cavalli, A., Maggioni, A. P., and Volpi, A. 1987. "Flecainide Distribution in Human Tissues." $B r . J$. Clin. Pharmac. 24: 820-2.

[2] Tjandra-Maga, T. B., Verbesselt, R., Van Hecken, A., Mullie, A., and De Schepper, P. J. 1986. "Flecainide: Single and Multiple Oral Dose Kinetics, Absolute Bioavailability and Effect of Food and Antacid in Man." Br. J. clin. Pharmac. 22: 309-16.

[3] Aliot, E., Capucci, A., Crijns, H. J., Goette, A., and Tamargo, J. 2011. "Twenty-Five Years in the Making: Flecainide Is Safe and Effective for the Management of Atrial Fibrillation." Europace 13: 161-73.

[4] Moffat, A. C., Osselton, M. D., and Widdop, B. 2004. Clarke's Analysis of Drugs and Poisons. London: Pharmaceutical Press, 1035-6.

[5] Baselt, R. C. 2000. Disposition of Toxic Drugs and Chemicals in Man. Foster: Chemical Toxicology Institute, 357-8.

[6] Lynch, M. J., and Gerostamoulos, J. 2001. "Flecainide Toxicity: Cause and Contribution to Death." Legal Medicin 3: 233-6.

[7] Brazil, E., Bodiwala, G. G., and Bouch, D. C. 1998. "Fatal Flecainide Intoxication." J. Accid. Emerg. Med. 15: 423-5.

[8] Levine, B., Chute, D., and Caplan, Y. H. 1990. 
"Flecainide Intossication." J. Anal. Toxicol. 14 (5): 335-6.

[9] Romain, N., Giroud, C., Michaud, K., Augsburger, M., and Mangin, P. 1999. "Fatal Flecainide Intoxication." Forensic Since International 106: 115-23.

[10] O'Sullivan, J. J., McCarthy, P. T., and Wren, C. 1995. "Differences in Amiodarone, Digoxin, Flecainide and Sotalol Concentrations between Antemortem Serum and Femoral Post-mortem Blood." Hum. Exp. Toxicol. 14 (7): 605-8.

[11] Martindale, W., and Parfitt, K. 1999. Martindale: The Complete Drug Reference, 32th ed. London: Pharmaceutical Press.

[12] Fuke, C., Berry, C. L., and Pounder, D. J. 1996.
"Postmortem Diffusion of Ingested and Aspirated Paint Thinner." Forensic Science Inernational 78 (3): 199-207.

[13] Yoshitome, K., Miyaishi, S., Yamamoto, Y., and Ishizu, H. 2008. "Postmortem Increase of Flecainide Level in Cardiac Blood.” J. Anal. Toxicol. 32: 451-3.

[14] Boriani, G., Strocchi, E., Capucci, A., Callivà, R., Frabetti, L., Ambrosioni, E., et al. 1991. "Flecainide: Evidence of Non-linear Kinetics." Eur. J. Clin. Pharmacol. 41 (1): 57-9.

[15] Benijts, T., Borrey, D., Lambert, W. E., De Letter, A. E., Piette, M. H. A., Van Peteghem, C., et al. 2003. "Analysis of Flecainide and Two Metabolites in Biological Specimens by HPLC: Application to a Fatal Intoxication." J. Anal. Toxicol. 27: 47-52. 